\title{
Food preferences of Pike Perch, Sander lucioperca (Linnaeus, 1758) in Morocco.
}

\author{
Meriem BOUSSEBA ${ }^{I^{*}}$, Loubna FERRAJ $^{1}$, Sara OUAHB $^{1}$, Anouar $_{\text {OUIZGANE }}{ }^{1}$,Aziz EL MOUJTAHID ${ }^{1}$, Mohammed \\ DROUSSI $^{2}$, and Mustapha HASNAOUI ${ }^{1}$ \\ ${ }^{1}$ Sciences and technologies Faculty, Sultan Moulay Slimane University, Beni-Mellal, Morocco \\ ${ }^{2}$ International expert in aquaculture, Morocco \\ *Email : meriembousseba@gmail.com
}

\begin{abstract}
Sander lucioperca hasbeen introduced in Morocco since 1939. This noble fish has shown a good ability to acclimatize to Moroccan conditions and has developed well [1]. The present study examines diet composition and predator-prey relationships that are dependent on size and weight between sander and its preys during the period October 2018-April 2019. Stomach contents of 287 specimens, whose size varies between 17 and $72 \mathrm{~cm}$, from Al-Massira dam, wereanalyzed. The results showed that Sander feeding is composed of six categories of prey, the most important species was the Blue gill (Perch) with an occurrence index equal to $14.9 \%$, the occurrence indices for other preys were respectively : Pike perch $(8.01 \%)$, Tilapia $(5.57 \%)$, Roach $(0.69 \%)$, Black bass $(0.69 \%)$ and Common carp $(0.69 \%)$. It has been found that the total length of the preys increases with that of the Pike perch. Thus, the Pike perch is able to ingest preys of big weight and size. We also revealed that cannibalism was high, indicating a lack of forage fish in this lake.
\end{abstract}

Keywords :Sander lucioperca, Al-Massira Dam, Food preferences.

\section{Introduction}

Pikeperch (Sander lucioperca, Linnaeus, 1758) is an ichthyophagous species nativeof eastern Europe where it is distributed from the east of the Elbe and around the Baltic Sea in the north and south-west. From Russia [2, 3, 4]. Due to interest that represents in the creation of sport and commercial fishing activities, it has become a favorite target for the anglers and fishcultirists.

Pike perch has a great interest in the valorization of water resources. It has major role in regulating phytophagous fish population, which are used to control the eutrophication of certain aquatic systems in order to improve the water quality.

This fish also has a socio-economic interest, particularly the creation of labors related to professional fishing activities. As a result, he was the object of several translocations in the world. Indeed, it was introduced at the end of the 30s (1939) of last century in the Moroccan aquatic ecosystems namely the lakes of the Middle Atlas, dam reservoirs and some rivers. Endowed with a remarkable facility of adaptation, it has developed perfectly in the big rivers and lakes Moroccan [1].

The study of fish diet in the wild can explain, on the one hand, growth variations, trophic migrations, and behaviors feeding. A lot of authors around the world have discussed the feeding of Sander in its various aspects [5-9]. In Morocco, despite of the ecological and socio-economic interest of this fish, studies dealing with its diet, its reproduction and other biological and ecological characteristics are absent in Morocco, which makes the fish development of this species difficult. Thus, the study of the diet of pikeperch will improve its production in Moroccan waters including dams, through improving the quantity and quality of its food.

In this context, the objective of this work is the study food preferences of adults of the pike perch
(Sander lucioperca) in Morocco which may help open new guidelines of research related the biology and ecology of this species in this country.

\section{Materials and Methods:}

\subsection{Field of study}

Located approximately 120 kilometers south-east of Casablanca at geographical coordinates $32^{\circ} 30^{\prime} \mathrm{N}-7$ ${ }^{\circ} 30^{\prime} \mathrm{W}, \mathrm{Al}$ Massira dam is one of the largest reservoirs in Morocco with a capacity of 2.5 billion m3. It is the second artificial reservoir in the country.

Built on the Oum Er Rbia wadi, Al Massira Dam is located in the arid bioclimatic stage with temperate winter [10]. Its importance is ensured for irrigation, drinking water and fish farming and is of great value for waterbirds. The reservoir dam is located at $285 \mathrm{~m}$ altitude.

\subsection{Sampling and analysis of stomach contents}

Our samples were collected from the fish market at Beni-Mellal city. The collection was carried out regularly during the period from October 2018 to April 2019. The sampled individuals come from the AlMassira Dam.

Sampling is carried out at least once a week (at least 7 individuals per sample), 287 Sander luciopercaspecimens whose size is between 17 and 72 $\mathrm{cm}$ and weight ranging from 50 to 3760 gwere processed and their diets were analyzed. For each fish, we recorded the total weight before evisceration, as well as the total length.

At the sampling site, the individuals were dissected and content of their digestive tract were recovered. The stomach contents of each individual were determined, then the non-ingested prey were identified and their weights and sizes were measured. 


\subsection{Expression of results}

To determine the diet of pikeperch (Sander lucioperca), we calculated a number of dietary indices based on the Lauzane method, 1976 [11].

$>$ Emptiness coefficient (EC) :

It is the percentage ratio between the number of empty stomachs (E.S) and the number of stomachs examined (S.E).

$$
E C=\frac{E . S}{S . E} \times 100
$$

\section{$>$ Abundance index (Iab) :}

It is the ratio of the number of a given prey (N.P) relative to the total number of prey (T.P) in percentage.

$$
I a b=\frac{N \cdot P}{T . P} \times 100
$$

\section{$>$ Occurrence Index (OI):}

It is the ratio of the number of stomachs in which a prey or category of prey is present (S.P) relative to the stomachs examined (S.E). This index provides information on dietary preferences.

$$
O I=\frac{S . P}{S . E} \times 100
$$

Volumetric index (VI) :
It is the ratio of the volume or weight of a category of prey (V.P) to the weight or total volume of prey consumed (T .V).

$$
V I=\frac{V . P}{T . V} \times 100
$$

In order to compare the importance of a category of prey in the diet, the Lauzanne food index (1975) [11] was used.

$$
F I=\frac{\% O . C x \% V . I}{100}
$$

This composite index, which varies from 0 to 100 , is useful for comparing the relative importance of different preys in the diet [12]. This index also provides information on dietary preferences.

Thus, the prey can be classified in 4 categories according to the value of their food index:

IA < 10: prey of secondary importance;

$10<\mathrm{IA}<25$ : important prey;

$25<\mathrm{IA}<50$ essentiel prey;

IA $>50$ : largely dominant prey;

\section{Result}

\subsection{Study of the diet}

During the period from October 2018 to April 2019, 287 individuals ranging in size from 17 to $72 \mathrm{~cm}$ and weighing varies between 50 and $3760 \mathrm{~g}$ were dissected and their stomach contents analyzed (Table1).

Table 1. Occurrence index, abundance index and volumetric index of Sander lucioperca.

\begin{tabular}{|c|c|c|c|}
\hline Prey & Iab :Abundence index & IO : Occurrence index & IV : Volumetric index \\
\hline Perch & 50,46 & 14,98 & 47,08 \\
\hline Sander & 23,85 & 8,01 & 27,97 \\
\hline Tilapia & 20,18 & 5,57 & 16,07 \\
\hline Gardon & 1,84 & 0,69 & 2,85 \\
\hline Black Bass & 1,84 & 0,69 & 5,06 \\
\hline Common carp & 1,84 & 0,69 & 0,95 \\
\hline
\end{tabular}

Stomach content analysis identified 107 preys with variability in size and weight, with an average of 1.2 prey per stomach and a mean weight of $14.7 \mathrm{~g}$ per prey. It should be noted that, of the 287 stomachs examined, 112 were empty, giving a vacancy index of $39.02 \%$.

Table 1 shows the different categories of prey found in the stomach of this fish. Thus, the diet of Sander comprises six categories of prey including,blue gillpike perch, tilapia, roach, black bass and common carp. Quantitatively, pikeperch has a dietary preference for Perch with $\mathrm{Iab}=50.46 \%$, IO $=14.98 \%$, followed by pikeperch and Tilapia with indices of abundance and occurrence respectively $(\mathrm{Iab}=23.85 \%$ ), OI $=$ $8.01 \%$ and $\mathrm{Iab}=20.18 \%$, OI $=5.57 \%$ ).
Table 2: Food index in Sander lucioperca.

\begin{tabular}{|c|c|c|}
\hline Preys & Food Index & Type of prey \\
\hline Perch & 7,05 & Secondary \\
\hline Sander & 2,24 & Secondary \\
\hline Tilapia & 0,89 & Secondary \\
\hline Gardon & 0,019 & Secondary \\
\hline Black bass & 0,034 & Secondary \\
\hline Common carp & 0,0065 & Secondary \\
\hline
\end{tabular}


Table 2 shows the food index values of different preys ingested by the Pikeperch. These results indicate that all preys are classified as secondary prey according to this index.

\subsection{Relationship between predator's size and weight with those of prey}

Fig 1 shows the relationship between preys size and that of the pike perch. Based on the results, preys size does not vary with predator size (Pike perch). However, we noted that $62.96 \%$ of the preys have a size less than or equal to $100 \mathrm{~mm} ; 32.40 \%$ have a size between 110 and $150 \mathrm{~mm}$ and only $4.62 \%$ have a size greater than $150 \mathrm{~mm}$. It should be noted that the maximum size of prey ingested by the pike perch isequal to $200 \mathrm{~mm}$, which is equivalent to approximately $(1 / 2)$ of its total length $(380 \mathrm{~mm})$.

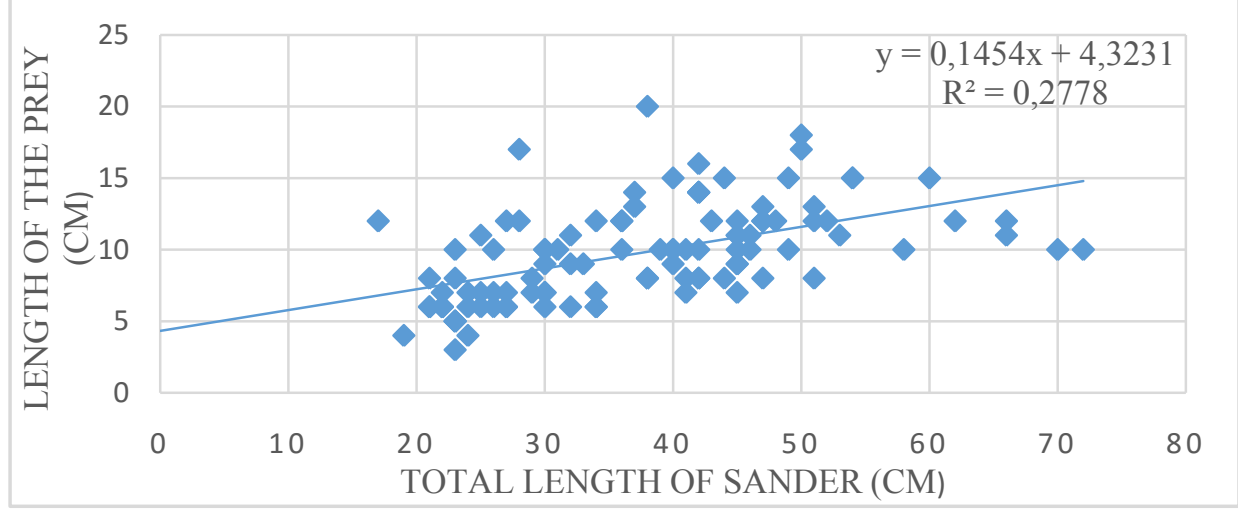

Fig. 1. Relationship between the total length of the Picke perch and the length of its prey.

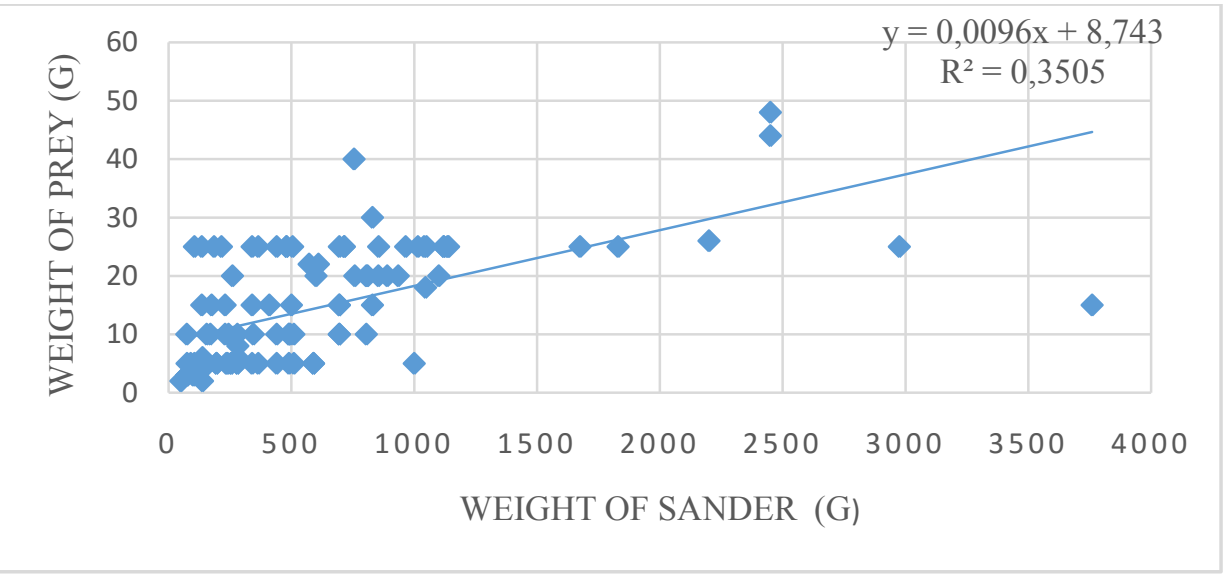

Fig. 2.Relationship between pike perch weight and prey weight.

Fig 2 shows the relationship between the weight of the Pike perch and the weight of the ingested prey. We noted ingested prey weight varies widely with Pike perch weight, with a minimum of $5 \mathrm{mg} / \mathrm{g}$ fresh weight, an average of $25.35 \mathrm{mg} / \mathrm{g}$ fresh weight and a maximumof $43.5 \mathrm{mg} / \mathrm{g}$ fresh weight. These results also show that regardless of the predator's weight, $38.31 \%$ consume prey less than $10 \mathrm{~g}, 38.31 \%$ ingest prey between 10 and $20 \mathrm{~g}$ and $23.36 \%$ exceed $20 \mathrm{~g}$. Thus, Pike perch may consumes small, medium and large item. 


\subsection{Size-related and seasonal changes of feeding}

The Variations of the coefficient of occurrence in Sander lucioperca of different sizes demonstrated a change in the choice of prey. For the first size class $<25$, the pike perch feeds on different types of prey (perch, pike perch, tilapia and undetermined prey) which are all accidental. (Fig 3.a, b). The diet of pike perch is mainly enriched with perch and pike perch with the increase in its body length.

For size classes between 25 and 59, sander eat more diverse prey, based on perch, zander, tilapia, roach, black bass, common carp and other indeterminate species.

The coefficient of occurrence of the perch changes for the size class between 53 and 59, which becomes accessory prey for pike perch $(\mathrm{IO}=31.03$; $\mathrm{Iab}=83.33)$
Beyond $59 \mathrm{~cm}$, the pike perch adopts a less diversified diet based on perch, pike perch and tilapia, so that the coefficient of occurrence of the perch changes and becomes accidental. Cannibalism was observed in almost all length groups of sander.

The seasonal changes in the zander diet are illustrated in Fig 4, a.b. From these results, we find that all the prey is accidental during the months (fig 4, a). The perch represented the most abundant prey during the months of December, January, March and April with abundance indices, which are respectively equal to $88.88 \%, 65.21 \%, 62.5$ and $94.44 \%$. For the month of October, pike perch occupied the highest abundance

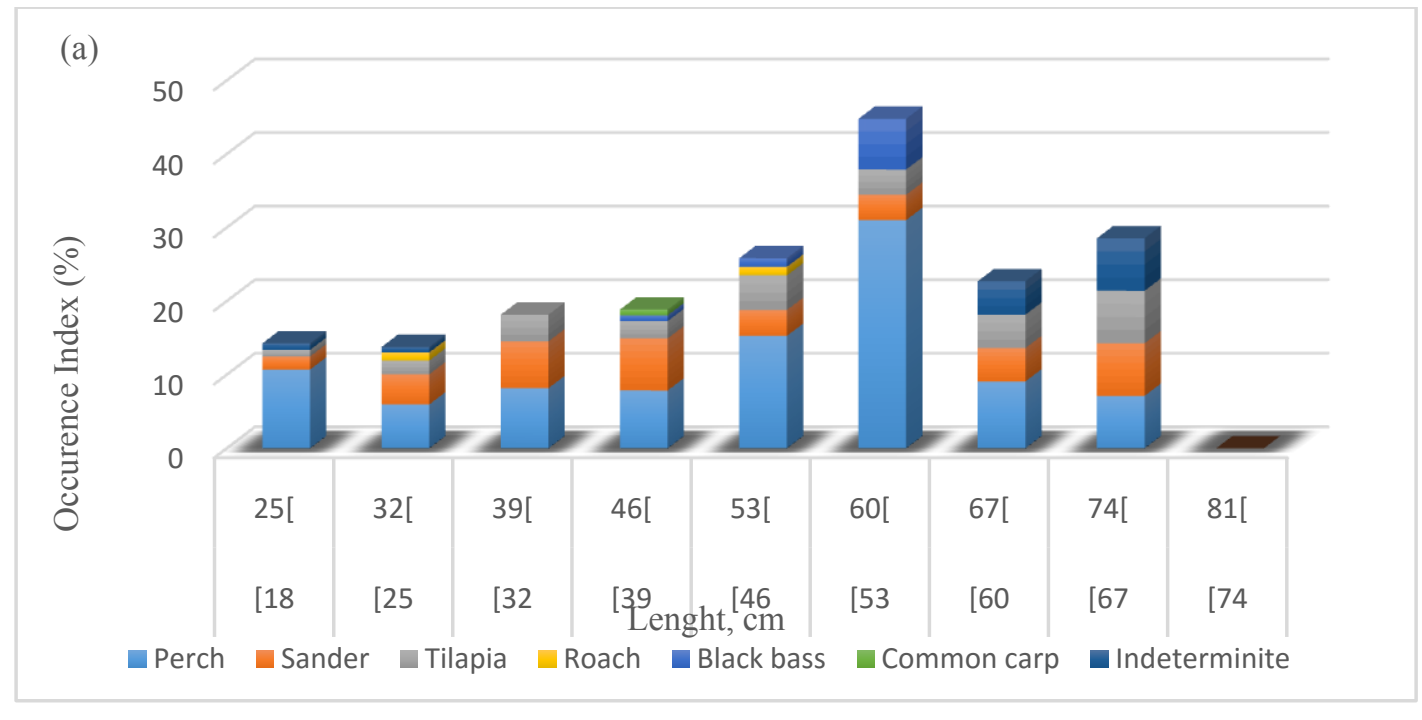

(b)

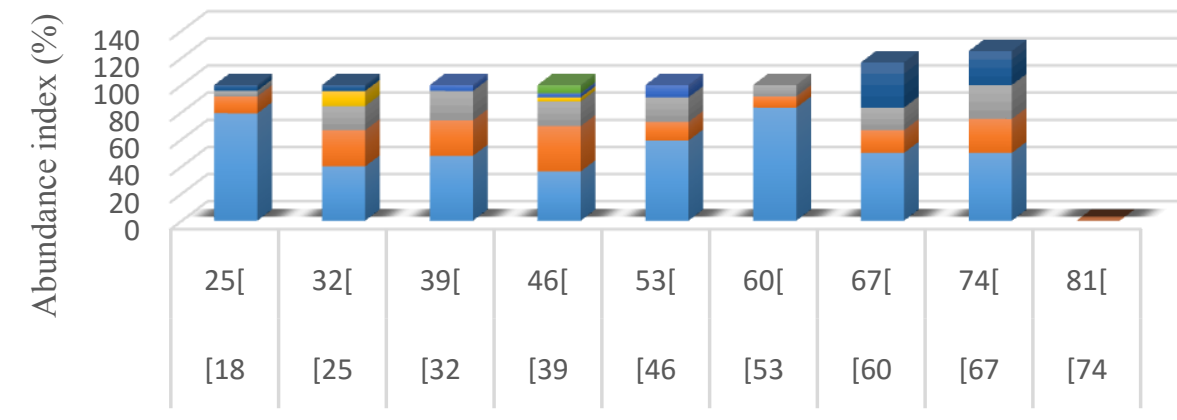

Lenght, $\mathrm{cm}$

- Perch Sander Tilapia Gardon Black bass Common carp Indeterminate

Fig. 3. Size-related variation (a) in the occurrence index (\%) and (b) abundance index prey (\%) in the diet of pike perch. 
index (93.75\%). Tilapia was the most abundant prey in February $(\mathrm{Ia}=50 \%)$ and had a lower abundance for the months January and March: 26.03\% and 25\%. While roach $(23.8 \%)$ and common carp $(12.5 \%)$ are the most

\section{Discussion}

This study showed that the diet of Sander at the AlMassira Dam consists of six categories of prey (Perch, Pikeperch, Black bass, Tilapia, Roach and Common Carp). The food spectrum shows dominance of Perch $(50.46 \%)$ followed by pikeperch $(23.85 \%)$ and Tilapia important prey in spring (months March and May respectively). The black bass was the most abundant prey in November with a more or less low abundance index

$(15 \%)$
$(20.18 \%)$. The other preys are less than $2 \%$. Other studies carried out on the diet of Sander at Camargue level in France [13] and in Algeria at the Cape Djenat reservoir and the Ghrib dam [14], have shown a more

(a)

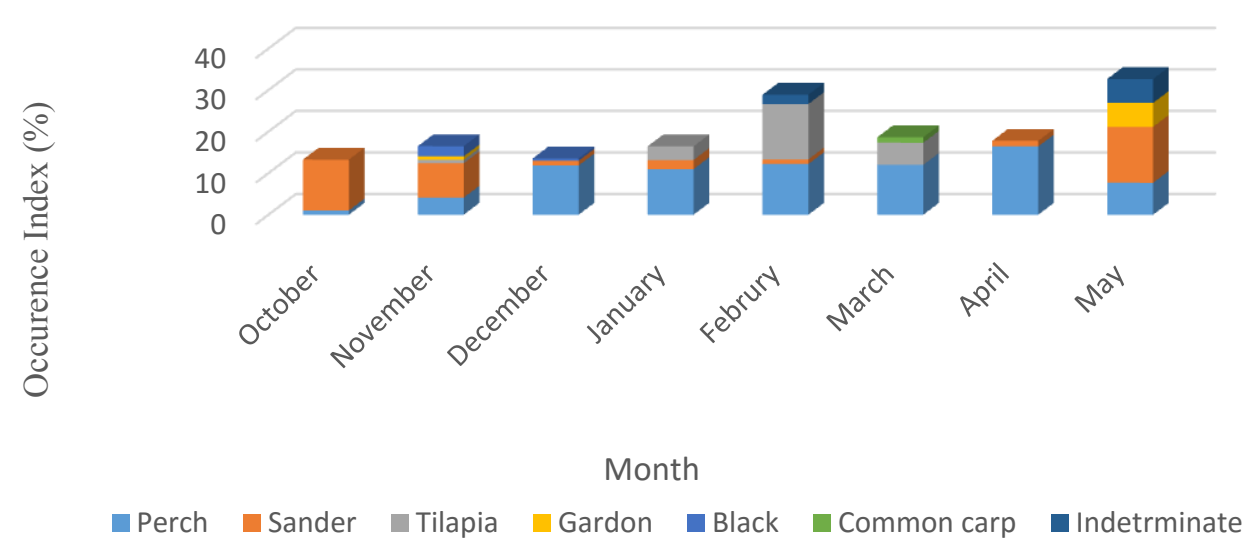

(b)
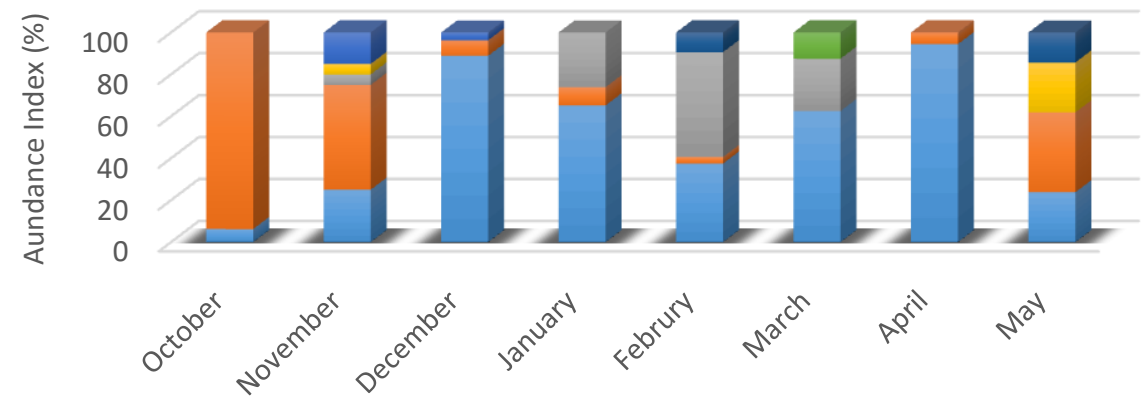

Month

a Perch Sander Tilapia Gardon Black bass a Common carp $\square$ Indeterminate

Fig. 4. Seasonal variation (a) in the occurrence index (\%) and (b) abundance index prey (\%) in the diet of pike perch.

diversified food of pikeperch which consists of a wide range of prey: Ablette, Athérine, Bream, Crustacean, Crustacean, Epinoche, Mullet, Perche Sun, Pseudorasbora and Rotengle.
The studies conducted by [15] and [16], showed that adult pike perch has an opportunistic eating habits, it feeds on the most abundant prey in its biotope. The dominance of this blue gill in Al massira Dam compared to other pre, explain this behavior and the 
results found in this study. These results are similar to those reported by [17] who found that sander may change prey selection quite rapidly in response to changes in abundance and vulnerability of prey species. The same behavior is observed in other carnivores including the case of Black Bass. Indeed, studies that have been done on the diet of this fish have shown that the Black Bass is an opportunistic predator; it feeds on the most abundant prey in its biotope [18, $19]$.

The degree of cannibalism observed in Al-Massira Dam Lake was high (about $40 \%$ of the fish eaten by Pikeperch). This degree of cannibalism is higher than that reported by [20] in Lake Ijssel (0-14\%)The scarcityof cannibalism was an indicator of forage fish abundance. In other populations, cannibalism can also be high, [21]found that this rate was $30 \%$ in Lake Balaton, this frequency is higher in Lake Egirdir and is equal to $96 \%$ [22].

In [23] and other authors, have shown that the phenomenon of cannibalism in pikeperch occurs, in case of scarcity of prey species and abundance of small pike perch. This phenomenon is considered asan important factor in regulating Sander populations [24]. This behavior explains the results found during our study (presence of pikeperch fry in the food of the adult pikeperch).

This study also revealed that pikeperch can swallow prey sizes that can be more than $150 \mathrm{~mm}$, which is in agreement with the results of [25] and [20], who found that prey size increases. With the size of the pikeperch and most predators. [26] who show that the preferred prey for the pikeperch is small fish 8 to $10 \mathrm{~cm} \mathrm{long,}$ such as dowels, bleaks or small roaches.

The results revealed that the largest size of prey swallowed by Pike perch $($ Size $=380 \mathrm{~mm}$ ) is equal to $200 \mathrm{~mm}$, which corresponds to approximately $1 / 2$ of its total length and can ingest up to $43.5 \mathrm{mg} / \mathrm{g}$ of his fresh weight. This result is superior to that found by [25] and [20].These authors have found that pikeperch can swallow prey up to $1 / 3$ of its total length in Dutch eutrophic lakes.

Based on the results, we also revealed that the small zander $(<25)$ feeds on different types of prey, all of which are accidental. [27] demonstrated that sander of age class $0+$ feeds mainly on zooplankton, chironomids and fish. This study also revealed that the pike perch, whose size between 25 and 73, has a diversified diet based on perch, pike perch, tilapia, roach, black bass, common carp and other indeterminate species. These results show that the diet of sander changes with age, omnivorous by being juvenile, then becomes strictly piscivorous with the oldest, which coincides with the data of [28] who revealed that specialized piscivores like zander move from zooplankton to a fish-based diet at an early stage in their life cycle. [15] also observed that pike perch often becomes fish-eating during its first summer, but fish can already constitute a considerable proportion in its diet when the length of pike perch is $23 \mathrm{~cm}$. These are in agreement with the results of [28] who revealed that the sander diet of more than $32.5 \mathrm{~cm}$ was mainly of fish. According to [29], the pike perch is generally fish-eating after reaching a length of $6 \mathrm{~cm}$.

We have seen seasonal changes in the sander diet, with an abundance of perch in winter and spring. These annual variations in the sander's eating habits are closely linked to the season of seasonal abundance of food. On the other hand, these dietary changes can be largely linked to the morphology of the pike perch since it is characterized by a mouth opening which is limited $[16,26]$. Our results also confirmed that small pike perches cannot handle prey species that are large such as carp, but they can handle elongated species such as perch and sander as prey, which confirms that the number and type of prey are affected not only by the total number of predators present in a body of water, but also by the size structure of their population [17]. These results are in agreement with the work of [30] who found that at Lake Virtsjrv, the pike perch may not be able to eat large individuals of deep-bodied prey species such as than bream, but it can feed on more elongated species such as smelt., the modal length of sander prey varied, depending on the species, between 5 and $7 \mathrm{~cm}$. In Finland, small sander eat small, elongated species such as smelt and bleak, while larger ones eat roach and perch [31]. The same is partially true for the pike perch in the Kaniv reservoir, where the pike perch consumed mainly small, elongated gobids, while roaches became more important in feeding the larger pike perch. However, th perch was more important prey in smaller groups of pike perch.

\section{Conclusion}

This study presents the results of the diet of Sander lucioperca and to appreciate the use of food available in continental environments at the Al-Massira reservoir.At the end of our study, we found that the pikeperch feeds on six categories of prey with an abundance of perch $(50.46 \%)$. When a prey species is abundant, it becomes the almost exclusive food of pikeperch.The size of the prey increases with the size of the pikeperch. Indeed, it is able to ingest preys equivalent to $1 / 2$ of its total length and up to $43.5 \mathrm{mg}$ / $\mathrm{g}$ of its fresh weight. 
1. A. Azeroual, Monographie des poissons des eaux continentales du Maroc: Systématique, Distribution et Ecologie. Université Mohammed V Agdal. Faculté Des Sciences Rabat. 164 p (2003).

2. C. Deelder \& J. Willemsen, Synopsis of biological data on pike-perch Lucioperca lucioperca (Linnaeus, 1758), Rome, 52 p (1964).

3. L. Horvath, G. Tamas \& L. Tolg, Special methods in pond fish husbandry. John E. Halver Ed., 146 p (1984).

6. M.A. YAĞCI, A. ALP, A. YAĞCI and R. UYSAL, Diet AND PREY SELECTION OF PIKEPERCH (SANDER LUCIOPERCA LINNAEUS, 1758) POPULATION IN LAKE EĞİRDİR TURKEY. Archives of Biological Sciences, 66 (4), 15151527, (2014).

7. C. Argillier, M. Barral, P. Irz, Growth and diet of the pikeperch Sander lucioperca (L.) in two French reservoirs. Archives of Polish Fisheries, 11(1): 99114 (2012).

8. M. M'Hetli, Le sandre Stizostedion lucioperca ( Linnaeus, 1758), téléostéen percidae allochtone : étude biologique et essai d'optimisation des critères d'élevage. Thèse de doctorat en sciences biologiques, Université de Tunis El Manar, 136 p (2001).

9. J. GOUBIER, Nourriture du Sandre Lucioperca lucioperca (L.). Bulletin Français de pêche et de pisciculture 263 : 77-79 (1976).

10. J. Emberger, Une classification biogéographie des climats. Rev. Trav. Botan et Zool. Faculté des sciences. Montpellier. Ser. Botan (1955).

11. L. Lauzanne, Régimes alimentaires et relations trophiques des poissons du lac Tchad. Cah. O.R.S.T.O.M., Série Hydrobiol. Vol. X (4) : 267310 (1976).

12. D. PAUGY, C. D'LEVEQUE, Diets and food webs. In Lévèque, C. \& D. Paugy, (eds): The fish of the continental waters of Africa: Diversity, ecology, use by the man. IRD editions, Paris: pp 167-190 (1999).

13. N. Poulet N, Le sandre (Sander Lucioperca (L)) : Biologie, comportement et dynamique des populations en Camargue (Bouche du Rhone, France). Thèse, Université de Toulouse III- Paul Sabatier, 300 p (2004).

14. BELAIFA et al. Comparaison du régime alimentaire du sandre Sander lucioperca (L., 1758) dans deux systèmes lacustres algériens.4th International Congress of the populations \& Animal Communities "Dynamics \& Biodiversity of the terrestrial \& aquatic Ecosystems"'CIPCA4"TAGHIT (Bechar) ALGERIA.

15. V. Erm, Koha. Valgus, Tallinn, 127 p (1981).
4. L. Sonesten, The biology of pikeperch- a literature review. Information fran Sotvatenss-laboratoriet Drottningholm 1, 68-71 (1991).

5. E.T. Nolan and JR. Britton, Diet of invasive pikeperch Sander lucioperca : developing nondestructive tissue sampling for stable isotope analysis with comparisons to stomach contents analysis. Knowl. Manag. Aquat. Ecosyst. 419, 49 (2018).

16. S. Salonen, H. Helminen \& J. Sarvala, Feasibility of controlling coarse fish populationsthrough pikeperch (Stizostedion lucioperca) stocking in Lake Kylinjrvi, SW Finland. Ann. Zool. Fenn., 33, 451457 (1996).

17. O.A. POPOVA, The role of predacious fish in ecosystems. In Ecology of Freshwater Fish Production (Gerking, S. D., ed.), Blackwell, Oxford, pp. 215-249 (1978).

18. A. Ouizgane, Etude des caractéristiques biologiques du Black bass (Micropterus salmoïdes) et de sa dynamique dans les étangs en polyculture avec le Tilapia du Nil (Oreochromis niloticus) et les carpes (Ctenopharyngodon idella, Hypophthalmichthys molitrix et Cyprinus carpio) sous climat semiaride (Station de pisciculture Deroua, Maroc).Université Sultan Moulay Slimane, Béni-Mellal. 132 p (2017).

19. F.N. Godinho, M.T. Ferreira , and R.V. Cortes , The environmental basis of diet variation in pumpkinseed sunfish, Lepomis gibbosus, and largemouth bass, Micropterus salmoides, along an Iberian river basin. Environ. Biol. Fishes, 50: 105115.A13 (1997).

20. J. Willemsen, Population dynamics of percids in Lake Ijssel and some smaller lakes in The Netherlands. J. Fish. Res. Board Can. 34, 17101719 (1977).

21. P.Biro, L. EIek L, The spring and summer nutrition of the 300--500gm pikeperch (Lucioperca lucioperca) in L. Balaton in 1968. Annales Instituti Biologici, Tihany, Hungaricae Academiae Scienlarum 36, 135-162 (1969).

22. R. N. B. CAMPBELL, Food of an introduced population of pikeperch, Stizostedion lucioperca L., in Lake Egirdir, Turkey. J. Aquat. Fish. Manage. 23, 71-85 (1992).

23. J. Bruslé \& J.P. Quignard, Biologie des poissons d'eau douce européens. Collection Aquaculture Pisciculture. Editions TEC \& DOC. Paris. $625 \mathrm{p}$ (2001).

24. P. Frankiewikz, K. Dabrowski, A. Martyniak, M. Zalewski , Cannibalism as a regulatory force of pikeperch, Stizostedion lucioperca (L), population dynamics in the lowland Sulejow reservoir (Central Poland). J. Hidrobio 409, 47-55 (1999). 
25. O.A. Popova \& L.A. Sytina, Food and feedding relations of Eurasian perch ( Perca Fluvatilis) and pikeperch (Stizostedion lucioperca) in various waters of the USSR. J. Fish. Res. Board. Can 34, 1559-1570 (1977).

26. P.A. SMITH, R.T. LEATH \& J.W. EATON, A review of the current knowledge on the introduction, ecology and management of Zander, Stizostedion lucioperca, in the UK. In Stocking and Introduction of Fish (Cowx, I. G., ed.). Fishing News Books. pp. 209-224 (1998).

27. BUIJSE A.D. \& HOUTHUIJZEN R.P., 1992. Piscivory, growth, and size-selective mortality of age 0 Pikeperch (Stizostedion lucioperca). Canadian Journal of Fisheries and Aquatic Sciences 49: 894-902.
28. Persson, A. \& Brnmark, C. 2002. Foraging capacity and resource synchronization in an ontogenetic diet switcher, pikeperch (Stizostedion lucioperca). Ecology, 83, 314322

29. Fickling, N. F. 1986. The feeding characteristics of the zander. In Proceedings of the 4th British Freshwater Fish Conference, pp. 193202. University of Liverpool, UK.

30. Peeter Kangur, Andu Kangur, and Klli Kangur. 2007. Dietary importance of various prey fishes for pikeperch Sander lucioperca (L.) in large shallow lake Virtsjrv (Estonia). Proc. Estonian Acad. Sci. Biol. Ecol., 56, 2, 154167.

31. Peltonen, H., Rita, H. \& Ruuhijrvi, J. 1996. Diet and prey selection of pikeperch (Stizostedion lucioperca (L.)) in Lake Vesijrvi analysed with a logit model. Ann. Zool. Fenn., 33, 481487. 